\title{
Blue-ice areas in Antarctica derived from NOAA AVHRR satellite data
}

\author{
Jan-Gunnar Winther, ${ }^{1}$ Martin Nørman Jespersen, ${ }^{2 *}$ Glen E. Liston ${ }^{3}$ \\ ${ }^{1}$ Norwegian Polar Institute, Polar Environmental Centre, N-9296 Tromsø, Norway \\ ${ }^{2}$ Technical University of Denmark, Copenhagen, DK-2800 Lyngby, Denmark \\ ${ }^{3}$ Department of Atmospheric Science, Colorado State University, Fort Collins, Colorado 80523, U.S.A.
}

\begin{abstract}
We have mapped Antarctic blue-ice areas using the U.S. National Oceanic and Atmospheric Administration (NOAA) Advanced Very High Resolution Radiometer (AVHRR) Antarctica cloud-free image mosaic established by the United States Geological Survey. The mosaic consists of 38 scenes acquired from 1980 to 1994. Our results show that approximately $60000 \mathrm{~km}^{2}$ of blue ice exist for each of the two main types of blue ice: "melt-induced" and "wind-induced". Normally, the former type is located on slopes in coastal areas where climate conditions (i.e. persistent winds and temperature), together with favourable surface orientation, sustain conditions for surface and nearsurface melt. The latter blue-ice category occurs near mountains or on outlet glaciers, often at higher elevations, where persistent winds erode snow away year-round, and combined with sublimation creates areas of net ablation. Furthermore, we have identified an additional area of $121000 \mathrm{~km}^{2}$ as having potential for blue ice. However, in these areas features such as mixed pixels, glazed snow surfaces, crevasses and/or shadows make interpretation more uncertain. In conclusion, a conservative estimate of Antarctic blue-ice area coverage by this method is found to be $120000 \mathrm{~km}^{2}$ ( $\sim 0.8 \%$ of the Antarctic continent), with a potential maximum of $241000 \mathrm{~km}^{2}$ ( $1.6 \%$ of the Antarctic continent).
\end{abstract}

\section{INTRODUGTION}

The majority of Antarctica consists of a snow-covered, interior ice sheet. In coastal areas, the snow and ice drain through ice streams that, further downstream, form floating ice shelves along the continent perimeter. Some mountainous areas exist such as in the Trans-Antarctic Mountains and on the Antarctic Peninsula. Blue-ice areas, i.e. areas of net annual ablation where glacier ice is exposed for parts of the year, are relatively small and generally located in coastal or mountainous regions.

The first glaciological investigations of blue-ice areas were made during the 1949-52 Norwegian-British-Swedish Antarctic Expedition (Schytt, 1961). After 1969, the blue-ice areas received more attention due to the discovery of meteorites on a blue-ice field in the Yamato Mountains (Yoshida and others, 1971). Blue-ice areas have also been mapped because of their potential as airfield sites (Mellor and Swithinbank, 1989; Swithinbank, 1991). More recently, there have been various studies focusing on blue-ice areas and their importance for the surface energy balance (Bintanja and Van den Broeke, 1995a, b; Van den Broeke and Bintanja, 1995) and for surface and subsurface melt-processes (Bøggild and others, 1995; Winther and others, 1996; Phillips, 1998; Liston and others, 1999a, b). Orheim and Lucchitta

* Present address: Norwegian Water Resources and Energy Administration, N-7075 Tiller, Norway.
(1990) suggested blue-ice areas as climate-change indicators, while Van den Broeke (1997) mapped spatial and temporal variations of sublimation with a high-resolution general circulation model (GCM). A comprehensive review of the glaciological, meteorological and climatological significance of blue-ice areas can be found in Bintanja (1999).

The motivation for our study is mainly twofold. First, we wanted to take advantage of the existing U.S. National Oceanic and Atmospheric Administration (NOAA) Advanced Very High Resolution Radiometer (AVHRR) nearly cloud-free mosaic that covers the entire Antarctic continent, to locate and quantify areas of blue ice. Blue-ice areas, with their low albedo (0.5-0.6) compared to that of snow (0.8-0.9), are easily monitored from space and may serve as a potential indicator of climate change if remeasured later. To date, the mosaic is the only optical remotely sensed dataset available with complete continental coverage. The more recent RADARSAT mosaic image covering Antarctica may provide further insight into, and improvements of, the mapping and monitoring of blue-ice areas, but has not been considered here.

Second, this work is an initial step for calculating the contribution from surface and near-surface melt to the mass balance of Antarctica. Previously, we have established a model for surface and near-surface melt based on detailed field studies in Dronning Maud Land (Liston and others, 1999b). In the future, we will calculate the meltwater production over the continent based on the occurrence of blue-ice areas mapped in this study, in combination with the United States Geological Survey (USGS) Antarctic digital elevation model (DEM) and data from Antarctic climatological stations. 




Fig. 1. Scene locations of the NOAA AVHRR mosaic image of Antarctica as well as final classification of blue-ice areas. Groundtruth data from Dronning Maud Land (upper, central part of the figure) and Lambert Glacier/Amery Ice Shelf (righthand side) used for verification are discussed in detail in the text. Note that in Table 1, blue-ice areas inside scene 10 are included in scene 9, the westerly "island" of scene 12 is included in scene 11, the easterly "island" of scene 12 is included in scene 13, and the group of "islands" in scene 20 are included in scene 23.

\section{THE NOAA AVHRR MOSAIC}

Although the AVHRR scans a $2400 \mathrm{~km}$ wide swath and can image nearly half of the Antarctic continent on a single orbit, 63 sections of 38 scenes were needed to compile the nearly cloud-free digital image mosaic. Initially, in 1985, the U.K. National Remote Sensing Centre (NRSG) mosaicked, controlled and geometrically corrected a digital polar stereographic image mosaic consisting of 24 scenes (Merson, 1989). Later, the initial image mosaic was evaluated and modified by USGS Flagstaff Field Center, Arizona, by including more scenes and filtering, re-sampling and enhancing the original mosaic (Ferrigno and others, 1996; personal communication from J. G. Ferrigno, 1999). The geometric accuracy of the upgraded mosaic has been estimated to have a rms error of $2.5 \mathrm{~km}$. The pixel size is $1.01 \mathrm{~km} \times 1.01 \mathrm{~km}$; AVHRR band 1 (580-680 nm) and AVHRR band $2(725-1100 \mathrm{~nm})$ are available separately at http://terraweb.wr.usgs.gov/TRS/projects/ Antarctica/.

Additionally, the USGS Earth Remote Observation Systems (EROS) Data Center provides access to a DEM over Antarctica that, like the AVHRR mosaic, is in a polar stereographic projection with $1.01 \mathrm{~km}$ resolution. The DEM has not been used in this study. Figure 1 shows scene locations and numbering as well as our final continental classification of blue-ice areas (see also Table 1).

\section{THE LANDSAT THEMATIC SPATIAL REFERENGE DATASET}

Due to its high spatial resolution of $30 \mathrm{~m}$, the Landsat Thematic Mapper (TM) was used to provide "reference" data to validate the AVHRR blue-ice classification. Further, Landsat TM bands 2 and 4 correspond spectrally well with AVHRR bands 1 and 2, respectively, so these two Landsat TM bands were used to validate the AVHRR-derived blueice classification.

A Landsat TM scene from 8 February 1985 (i.e. band 1: 450-520 nm; band 2: 520-600 nm; band 3: 630-690 nm; band 4: $760-900 \mathrm{~nm}$ ) was used to support the interpretation of AVHRR scene 11. The TM scene covers areas in Dronning Maud Land where high-resolution maps and extensive ground-truth data exist (Orheim and Lucchitta, 1990; Winther, 1993, 1994; Winther and others, 1996; Liston and others, 1999a, b, 2000) (Figs 2 and 3). 
Table 1. Final classification of blue-ice areas (in number of pixels) for individual scenes

\begin{tabular}{|c|c|c|c|}
\hline $\begin{array}{l}\text { Scene No.; date } \\
\text { of acquisition }\end{array}$ & $\begin{array}{c}\text { "Wind-induced" } \\
\text { blue ice }\end{array}$ & $\begin{array}{l}\text { "Melt-induced" } \\
\text { blue ice }\end{array}$ & $\begin{array}{c}\text { "Uncertain/potential" } \\
\text { blue ice }\end{array}$ \\
\hline 4; 11 Aug 1980 & $0(0.0)$ & $0(0.0)$ & $24(0.0)$ \\
\hline 5; 25 Jan 1980 & $1(0.0)$ & $54(0.1)$ & $1591(1.3)$ \\
\hline 6; 24 Nov 1980 & $3432(5.9)$ & $1(0.0)$ & $5318(4.5)$ \\
\hline 7; 25 Nov 1986 & $17(0.0)$ & $0(0.0)$ & $307(0.3)$ \\
\hline 8; 27 Dec 1987 & $4(0.0)$ & $0(0.0)$ & $43(0.0)$ \\
\hline 9; 11 Feb 1980 & $4378(7.5)$ & $0(0.0)$ & $8999(7.6)$ \\
\hline 11; 06 Feb ;1983 & $4179(7.1)$ & 5209 (8.8) & $3830(3.2)$ \\
\hline 13; 12 Apr 1986 & $2120(3.6)$ & $6828(11.5)$ & $4982(4.2)$ \\
\hline 14; 29 Jan 1987 & $0(0.0)$ & $1474(2.5)$ & $1968(1.7)$ \\
\hline 15; 15 Feb 1980 & $4673(8.0)$ & $2551(4.3)$ & $6823(5.8)$ \\
\hline 16; 21 Jan 1987 & $21751(37.1)$ & $18876(31.9)$ & $27628(23.3)$ \\
\hline 19; 18 Jan 1980 & $1923(3.3)$ & $1950(3.3)$ & $4269(3.6)$ \\
\hline 21; 16 Feb 1983 & $0(0.0)$ & $3847(6.5)$ & 4452 (3.8) \\
\hline 22; 04 Nov 1980 & $0(0.0)$ & $1329(2.2)$ & $643(0.5)$ \\
\hline 23; 14 Jan 1980 & $1(0.0)$ & 7278 (12.3) & $6673(5.6)$ \\
\hline 24; 29 Nov 1983 & $0(0.0)$ & $2290(3.9)$ & $2572(2.2)$ \\
\hline 26; 12 Jan 1980 & $2797(4.8)$ & $1520(2.6)$ & 12795 (10.8) \\
\hline 27; 17 Jan 1981 & $13(0.0)$ & $9(0.0)$ & $730(0.6)$ \\
\hline 28; 05 Jan 1992 & $9(0.0)$ & $1(0.0)$ & $6(0.0)$ \\
\hline 29; 12 Feb 1983 & $1132(1.9)$ & $0(0.0)$ & $766(0.7)$ \\
\hline 30; 12 Nov 1980 & 7685 (13.1) & $9(0.0)$ & 13592 (11.5) \\
\hline 31; 08 Dec 1992 & $2(0.0)$ & $0(0.0)$ & $3(0.0)$ \\
\hline 32; 21 Dec 1993 & $25(0.0)$ & $0(0.0)$ & $14(0.0)$ \\
\hline 33; 06 Nov 1980 & $1195(2.0)$ & $0(0.0)$ & $1692(1.4)$ \\
\hline 34; 08 Jan 1994 & $1874(3.2)$ & $0(0.0)$ & $2075(1.8)$ \\
\hline 35; 08 Nov 1980 & $1399(2.4)$ & $304(0.5)$ & $2932(2.5)$ \\
\hline 36; 11 Jan 1994 & $0(0.0)$ & $237(0.4)$ & $1176(1.0)$ \\
\hline 37; 13 Jan 1980 & $0(0.0)$ & $5439(9.2)$ & $2536(2.1)$ \\
\hline Total pixels & 58610 & 59206 & 118439 \\
\hline Total $\mathrm{km}^{2}$ & 59782 & 60390 & 120808 \\
\hline
\end{tabular}

Notes: Scene numbers not included had no blue ice identified in them. The percentage of blue ice for a given category and corresponding scene is shown in parentheses.
The TM scene was only used as "reference" within AVHRR scene 11 to improve AVHRR-derived blue-ice classification in this particular region. In other scenes, validation of the AVHRR blue-ice classification was supported by maps provided from a number of Antarctic national programmes, various field observations and measurements and the comprehensive registrations and oblique photographs from Swithinbank (1991).

\section{GLASSIFICATION OF BLUE-ICE TYPES}

Glacier ice is formed by compression of snow and contains numerous air bubbles. The fraction of light reflected increases as the bubble content increases (Warren and others, 1993). Also, snow crystals have the effect of increasing surface albedo due to the increased scattering and reflectance compared to pure glacier ice (Winther, 1994). We generally find higher concentrations of ice-bound snow crystals in the "melt-induced blue-ice" areas at lower elevations than in the "wind-induced blue-ice" areas due to repeated melt-freeze cycles that occur there (Winther 1994; Liston and others 1999b). This leads to a difference in spectral reflectance between the two blue-ice types (Winther 1994). Air-bubble content has not been measured, but we speculate that the bubble content in the melt-affected areas is higher due to the formation of superimposed ice. Sometimes, however, liquid water is present in the "melt-induced blue-ice" areas. This reduces the albedo, especially in the infrared wavelength region, and complicates separation of the two blue-ice types considerably. Thus, classification of these two blue-ice types would normally be achievable, but under special circumstances the spectral signatures are very similar.

In Dronning Maud Land, we selected two well-known blue-ice areas, i.e. Jutulsessen and Jutulstraumen, as primary (supervised) training sites (Figs 2 and 3). We classified the blue-ice areas in the Jutulstraumen coastal region as "melt-



Fig. 2. AVHRR mosaic scene 11 covering Dronning Maud Land. The main areas where blue ice occurs are shown. Futulsessen and futulstraumen have been used extensively for ground-truthing. 


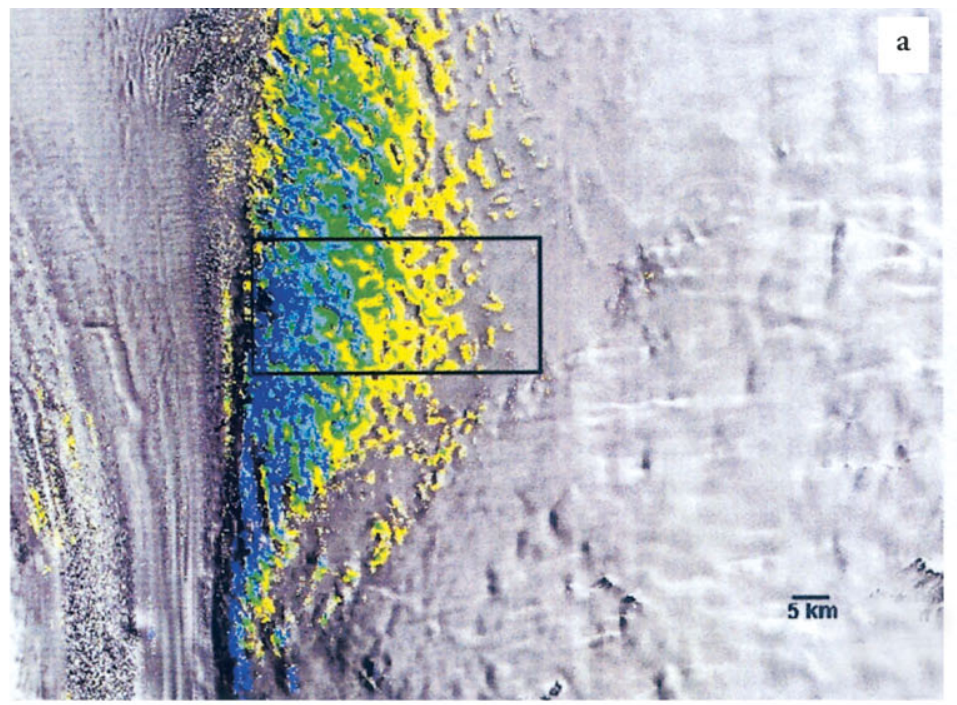

- Blue ice class A

- Blue ice class B

- Blue ice class C

Bne ice class D
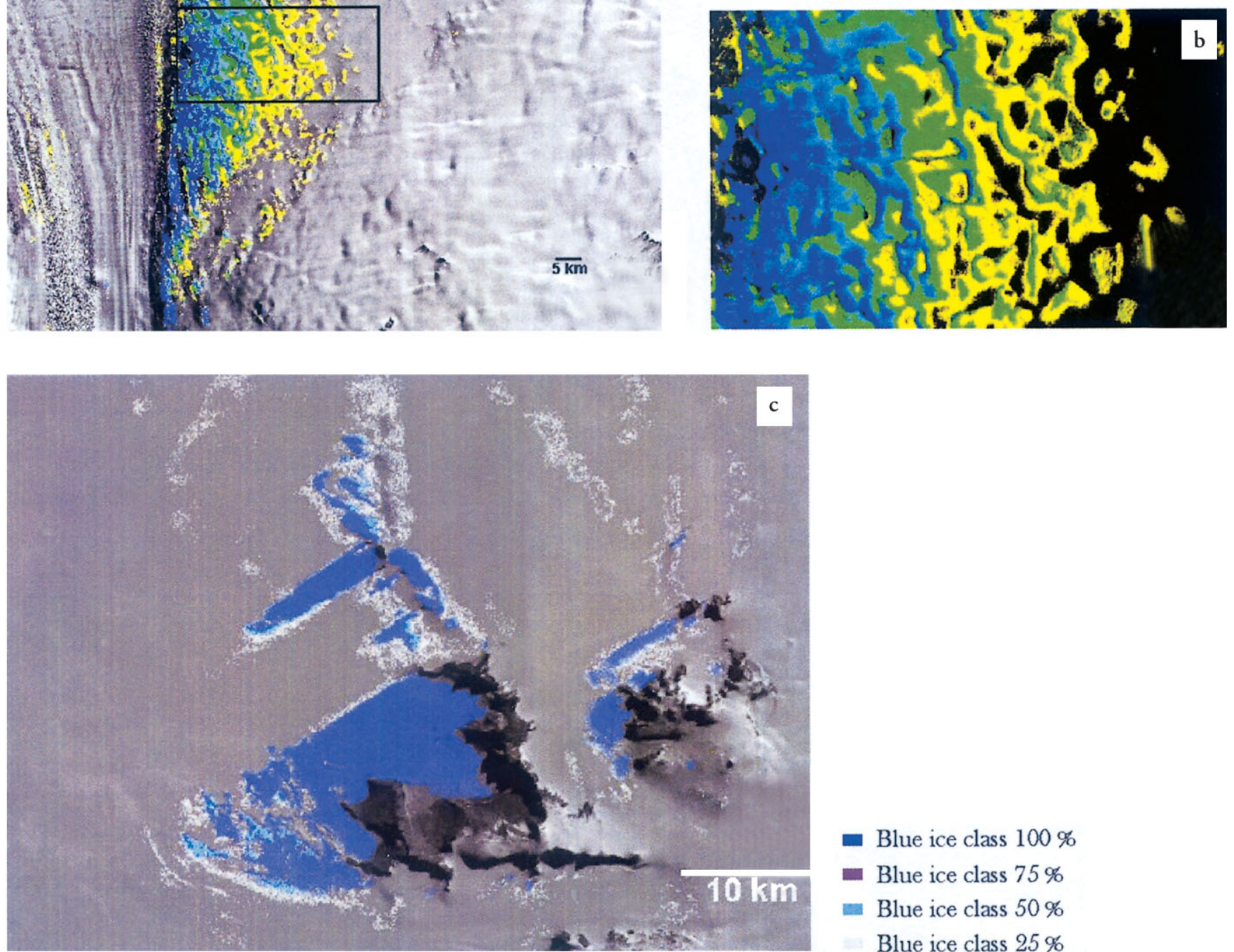

- Blue ice class $100 \%$

- Blue ice class $75 \%$

- Blue ice class $50 \%$

Blue ice class $25 \%$

\begin{abstract}
Fig. 3. ( a) Landsat TM blue-ice classification of a "melt-induced" blue-ice area in Futulstraumen. (b) Details of blue-ice and snow patterns inside the box shown in (a); a different stretching routine is applied here, so a change of aspect ratio compared to (a) appears. (c) Landsat TM blue-ice classification in Jutulsessen, where dark blue represents $100 \%$ blue ice while white colour indicates mixed pixels. Grey colour is snow-covered surfaces; black is nunataks. Note the sharp transition between blue ice and snow occurring in this "wind-induced blue-ice" area compared to futulstraumen.
\end{abstract}

induced", whereas those in Jutulsessen (located about $1250 \mathrm{~m}$ a.s.l.) were classified as "wind-induced", based on the primary process forming blue ice in these two areas (Orheim and Lucchitta, 1990; Bøggild and others, 1995; Winther and others, 1996; Liston and others 1999a, b).

\section{WEAKNESSES AND UNGERTAINTIES}

We rest our study on using an AVHRR mosaic that has been established from a number of scenes, recorded over many years (Table 1). This means that surface conditions are different from scene to scene in the mosaic. Because of the various dates of recording, we could, for example, experience the occurrence of extreme melt events or, on the other hand, snowfall episodes that would influence scenes in the mosaic very differently. Also, illumination conditions are different from scene to scene due to the different recording times.

Another weakness is that the AVHRR mosaic data have been highly processed from their original scenes. Thus, scenes have been processed differently and may not be directly comparable. As an illustration, in Figure 4 the range of digital numbers (DNs) in various scenes for AVHRR band 2 over blue ice and snow is shown. Here, we see a significant variation in range between scenes. It should be noted that AVHRR uses a 10-bit quantification of the satellite-received radiance and that this quantification is applied linearly over the corresponding radiometric range. The superior radiometric resolution of the AVHRR compared to Landsat TM, Système Probatoire pour l'Observation de la Terre (SPOT) and RESURS-01 compensates for its poorer spatial resolution (Bindschadler and Vornberger, 2000). Hence, by using the processed mosaic we are forced to work with DNs instead of radiances (or surface albedo), and also to work with DNs that not are comparable between scenes. This is a major shortcoming. Finally, the effect of different processing procedures is impossible to distinguish from the effects of different surface and illumination conditions. 
DN Range Blue ice (AMHRR2)
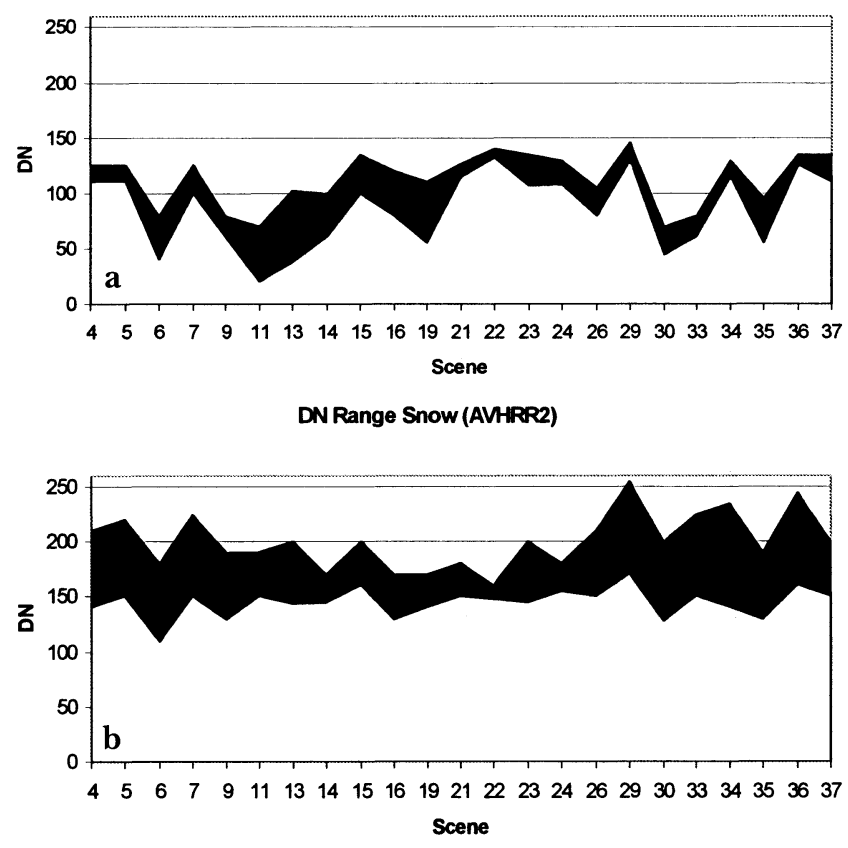

Fig. 4. DN ranges for AVHRR band 2 for ( $a$ ) snow and ( $b$ ) blue ice of all included scenes.

Further, AVHRR blue-ice classification is verified by comparing with one Landsat TM scene in one region of Antarctica. Even though we have an excellent knowledge of the area used for verification, it is doubtful how precisely AVHRR blue-ice classification can be transferred to other regions. This is exemplified in Figure 5 where "windinduced" blue ice is surrounded by a zone of "melt-induced" blue ice in some regions of the Lambert Glacier area. It is hard to give such a feature a physical explanation.

The different sensor resolution of NOAA AVHRR $(1.01 \mathrm{~km})$ and Landsat TM $(30 \mathrm{~m})$ introduces another problem, especially in blue-ice areas having a patchy occurrence or that are partly in the shade. The Landsat TM scene used for verification in Dronning Maud Land is recorded 2 years later than the AVHRR scene used for classification (scene No. 11, Table 1).
This is probably a less important weakness since the areas of blue ice are not expected to change rapidly.

Even with this long list of shortcomings we found it worthwhile to carry out a blue-ice mapping of Antarctica using the AVHRR mosaic. The strongest argument for doing so is that the mosaic is currently the only available optical satellite composite dataset with continental coverage, and as such contains a wealth of valuable information.

\section{METHODOLOGY}

To establish an almost $100 \%$ cloud-free mosaic image for Antarctica, USGS made use of 38 scenes recorded in austral summers 1980-94. As described previously, the variable surface characteristics and processing procedures of the mosaic limit the precision with which blue-ice areas can be mapped using this mosaic. Therefore, rather than develop blue-ice classification algorithms for the entire mosaic image, we decided to develop specific algorithms for blue-ice extraction for individual scenes. Thus, as an initial step, we separated scenes in the mosaic using principal-component analysis followed by high-pass filtering. This method successfully distinguished neighbouring scenes, either by evaluating neighbouring pixel values or by comparing divergent directions of the sensor scan-lines. The former were successfully obtained using the image of principal component No. 1 (PCl image), while the latter were achieved using the PC2 image.

As seen in Figure 1, blue-ice areas in Dronning Maud Land and the region of Lambert Glacier/Amery Ice Shelf contribute significantly to the continent-wide occurrence of blueice areas. Because of this, and also because we have considerable first-hand knowledge of blue-ice areas in Dronning Maud Land (Winther, 1993; Winther and others, 1996; Liston and others, 1999a, b), our ground-truth site selections have been primarily in Dronning Maud Land (i.e. Jutulsessen and Jutulstraumen) and secondly in the Lambert Glacier basin. Thereafter, the knowledge obtained in these regions was combined with supplementary ground-truth information (from publications, maps, photos and personal communication with scientists having local knowledge) and used in other scenes to (i) identify blue-ice areas and thereafter

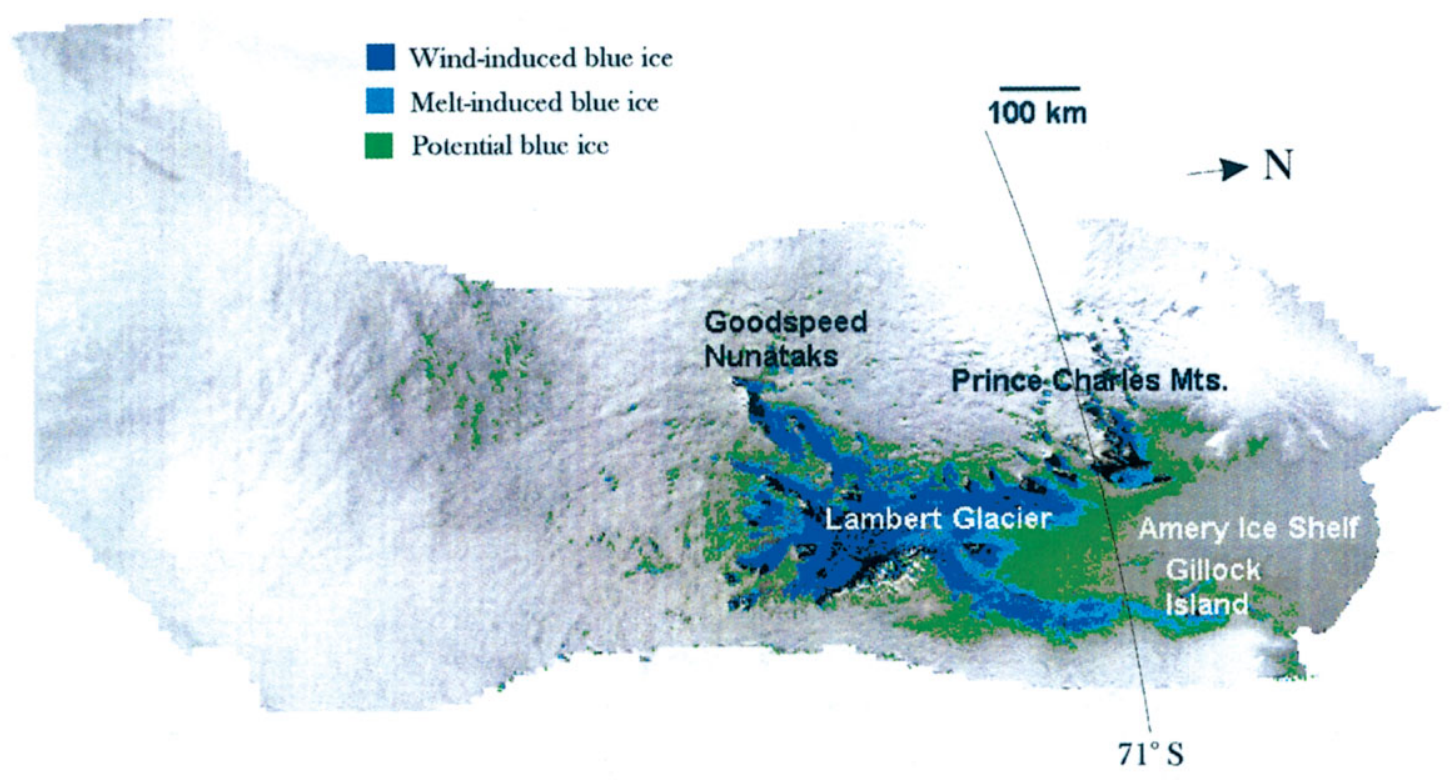

Fig. 5. AVHRR mosaic scene 16 covering the largest blue-ice areas of the Antarctic continent located in the Lambert Glacier basin. Dark blue indicates "wind-induced" blue ice, light blue indicates "melt-induced" blue ice, while green indicates areas where occurrence of blue ice is uncertain. 
Table 2. Landsat TM DN ranges of various surface types in Jutulsessen (TM band 4/2 ratio values have been radiometrically stretched)

\begin{tabular}{lccccc}
\hline TM band & Snow (horiz.) & Snow (sun) & Blue ice & Rock(sun) & Rock (shade) \\
\hline 1 & $255-255$ & $255-255$ & $255-255$ & $120-180$ & $180-255$ \\
2 & $155-170$ & $170-255$ & $130-150$ & $65-75$ & $25-40$ \\
3 & $185-230$ & $230-255$ & $155-175$ & $40-60$ & $70-90$ \\
4 & $130-160$ & $160-255$ & $60-95$ & $75-85$ & $20-35$ \\
$4 / 2$ & $90-105$ & $105-120$ & $60-75$ & $130-140$ & $105-115$ \\
\hline
\end{tabular}

include them in the supervised classification, and in other cases to (ii) verify the unsupervised classification of blue-ice areas.

The satellite images used are in the form of DNs $(0-255)$ assigned to each pixel. The DN defines how much radiation is reflected at the surface in a particular wavelength region (e.g. in TM band 4). This information is used to distinguish high-reflection (i.e. snow) from low-reflection surfaces (i.e. rock) (Tables 2-4). Spectral albedo measurements of snow and blue ice are reported by Warren and others (1993), Winther (1994) and Winther and others (1999, 2001). In Jutulsessen, for example, there exist prominent transitions between the three main surface types: dry snow, blue ice and mountains (Fig. 3c). The boundaries of each class have been extracted by investigating conservative pixel values that belong to a certain class, based on detailed local knowledge of this area. Table 2 summarizes the Landsat TM brightness ranges for the predominant surface features in Jutulsessen.

While pixel values within the given brightness ranges belong to a certain surface type, so-called "mixed pixels", consisting of more than one surface type, have DN located outside these ranges (Table 2). In this particular case this means that mixed pixels consisting of blue ice and snow have pixel values of $150-155$ in TM band 2 and 95-130 in TM band 4 (Table 2). Here, the mixed pixels span the widest range of DN in TM band 4, which then theoretically provides the best description of these surface areas. The reason for introducing a TM band $4 / \mathrm{TM}$ band 2 image (and later an AVHRR 2/AVHRR 1 image) is that while snow and blue ice are best discriminated in the infrared wavelength region (i.e. in TM band 4), the best discrimination of rock and blue ice is obtained using information from the visible part of the electromagnetic spectrum, i.e. in TM band 2 (Table 2).

Returning to the issue of mixed pixels, field investigations show that when moving from a blue-ice area towards a totally snow-covered area, a gradually increasing portion of the surface will be snow-covered. We have tested a simple linear relationship between pixel values at the borders of identified surface types such as snow and blue ice, and then calculated the percentage of blue ice present in each of the mixed pixels in these transition zones. This method would have allowed us to quantify the percentage of blue ice and include these areas in the main blue-ice category. However, we decided to treat areas where mixed pixels occur as a separate class, "uncertain/potential blue ice", since the actual conditions in such areas can be much more complex than described above. For example, several surface features with very different (and even unknown) spectral characteristics may be present in combination (e.g. crevasses, glazed snow surfaces and shadows).

For the "melt-induced blue-ice" class, using areas in
Table 3. Landsat TM DN ranges of various surface features in the Jutulstraumen area (TM band 4/2 ratio values have been radiometrically stretched)

\begin{tabular}{cccccc}
\hline TM band & $\begin{array}{c}\text { Snow } \\
\text { (east) }\end{array}$ & $\begin{array}{c}\text { Snow } \\
\text { (west) }\end{array}$ & $\begin{array}{c}\text { Blue ice } \\
\text { (east) }\end{array}$ & $\begin{array}{c}\text { Blue ice } \\
\text { (west) }\end{array}$ & $\begin{array}{c}\text { "Frozen } \\
\text { lakes" }\end{array}$ \\
\hline 1 & $255-255$ & $255-255$ & $255-255$ & $255-255$ & $255-255$ \\
2 & $145-160$ & $131-143$ & $140-143$ & $128-133$ & $65-115$ \\
3 & $173-185$ & $155-173$ & $161-168$ & $148-158$ & $80-140$ \\
4 & $103-140$ & $95-104$ & $93-105$ & $88-96$ & $25-80$ \\
$4 / 2$ & $11-13$ & 10 & $9-10$ & $9-10$ & $3-8$ \\
\hline
\end{tabular}

Jutulstraumen as supervised training sites, mixed pixels were treated in the same way as described above. Here, the reflective characteristics of snow and blue ice (i.e. surface albedo) are more similar than in the Jutulsessen area (Table 3). Brightness values (or snow albedo) are lower in Jutulstraumen because the snow has undergone major meltfreeze metamorphosis due to the relatively frequent surface melt occurring here. Additionally, the blue-ice areas have a more scattered appearance, thus causing more mixed pixels. Both these conditions make precise discrimination of snow and blue-ice areas more difficult in Jutulstraumen than in Jutulsessen (Fig. 3). This statement applies also in more general terms: separation of "melt-induced blue ice" and snow is more complicated than separation of "wind-induced blue ice" and snow. Additionally, we distinguished between blueice areas in west and east during the supervised classification since the westerly locations at low elevations are more influenced by melting and thus have lower surface albedo than those at higher elevations towards the east (Table 3). The main mechanism behind the lower albedo values in the western area is that conditions here favour repeated meltfreeze metamorphism which increases grain-size growth and lowers the infrared albedo.

The experience gained from the Landsat TM "reference" classification was used when classifying blue-ice areas with the AVHRR data. For example, AVHRR band 1 was generally used for selecting training areas close to mountains, while AVHRR band 2 was used near transitions between snow and blue ice because of their different reflective characteristics and ability to capture various surface features (Table 4). An AVHRR band 2/AVHRR band 1 image discriminator was used for large-scale blue-ice classification (Table 4).

Finally, the AVHRR band 2/AVHRR band 1 discriminator image was applied to the remaining parts of scene 11 (unsupervised classification). The image discriminator was then verified by comparing the classification with other ground-truth data, such as oblique air photos from Swithinbank (1991), observations from Schirmacher Oasis close to the former East German Georg Forster station (Lange,

Table 4. NOAA AVHRR DN ranges of various surface types in Futulsessen and Futulstraumen (AVHRR band 2/1 ratio values have been radiometrically stretched)

\begin{tabular}{cccccc}
\hline $\begin{array}{c}\text { AVHRR } \\
\text { band }\end{array}$ & $\begin{array}{c}\text { Snow } \\
\text { (horiz.) }\end{array}$ & $\begin{array}{c}\text { Snow } \\
\text { (sun) }\end{array}$ & Blue ice & Shaded areas & $\begin{array}{c}\text { Rock } \\
\text { (sun) }\end{array}$ \\
\hline 1 & $165-180$ & $180-255$ & $137-160$ & $75-130$ & $145-195$ \\
2 & $150-165$ & $165-190$ & $20-90$ & $20-25$ & $140-175$ \\
$2 / 1$ & $38-40$ & $40-47$ & $7-30$ & $8-11$ & $42-250$ \\
\hline
\end{tabular}




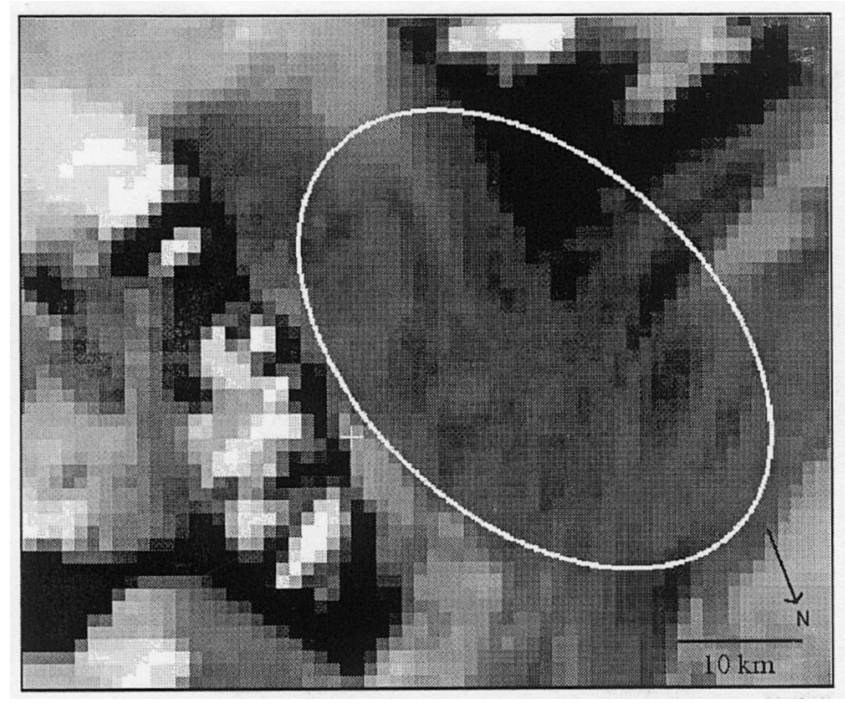

Fig. 6. "Wind-induced" blue ice on Beardmore Glacier. The brightest pixels are sun-exposed mountains, while the darkest pixels are shadows caused by mountains. The grey pixels inside the white ring are interpreted as blue ice, generated by winds at the lee side of the mountains.

1996), satellite-based Norwegian maps (1:250 000) and substantial local knowledge of this area. In general, the agreement was good. For example, satellite-derived classification discriminated very well between Schirmacher Hills (rock: black colour in Fig. 2) and Schirmacher Oasis (blue ice: blue colour in Fig. 2).

In the Lambert Glacier/Amery Ice Shelf region (Fig. 5) we used a combination of satellite maps (1:100 000) from the Australian Antarctic Division based on SPOTdata, 15 aerial photographs from Swithinbank (1991) and observations of blue-ice and other surface phenomena (Allison and others, 1985; Allison, 1998; Phillips, 1998; I. Allison and H. A. Fricker (née Phillips), personal communication, 1999). Both types, "melt-induced" and "wind-induced" blue ice, were identified in this region. Training sites for "wind-induced" blue ice were found at three locations in the vicinity of the Prince Charles Mountains. Sites corresponding to "melt-induced" blue ice were selected in areas near Gillock Island in the eastern part of the Amery Ice Shelf. In this region, we did not use Landsat TM images to improve AVHRR-derived blue-ice classification or to verify the classification made with AVHRR data.

The Transantarctic Mountains are a dominant feature of scene 30. Swithinbank (1991) describes 12 locations of blue ice, which are illustrated by aerial photographs. They are all located near mountains or on outlet glaciers. Blue-ice areas on Beardmore Glacier and around Mount Bumstead were used as training sites, as both clearly appear on photographs and in the AVHRR scene (Fig. 6). In this area, blueice classification consists only of the "wind-induced" and "potential/uncertain blue-ice" categories.

Above, four areas with large blue-ice areas and available ground-truth data have been described in some detail. The complete mosaic was classified scene by scene, repeating the methodology described above. Individual training sites available within various scenes have been used either for supervised classification purposes or to verify the selected classification algorithms. In total, we used 104 different reference sites for this study. The final results of the classifi- cation are presented in Table 1. More details about the methodology can be found in Jespersen (2000).

\section{RESULTS AND DISGUSSION}

In Jutulsessen, the following surface types were identified: (i) snow, horizontal terrain, (ii) snow, sun-exposed, (iii) blue ice, (iv) rock, sun-exposed and (v) rock, shaded (Table 2). ATM band 4/TM band 2 image was found to be a useful discriminator, enabling us to distinguish between snow, blue ice and rock, which is not possible when using only one band (Table 2). Next, to account for the occurrence of mixed pixels, we tested a linear relationship between TM band 4 reflectance of snow and blue ice, respectively. In this way we also calculated pixels containing $25 \%, 50 \%$ and $75 \%$ of blue ice. Due to the distinct transition between snow and blue ice in the Jutulsessen area, only a limited number of mixed pixels occur here (Fig. 3c). For the continent-wide classification, however, we did not make use of such a linear relationship due to the complexity of surface types often occurring in such areas (see section 6).

Further, as expected from observations, we observed that the radiometric difference between blue ice and snow is much larger in AVHRR band 2 than in AVHRR band 1 (Table 4), as with the results obtained from Landsat TM data. We also found that snow, blue ice and shaded areas could be well separated but that sun-exposed rock can be misinterpreted as snow (Table 4). In addition, shaded areas were more effectively discriminated from blue ice in AVHRR band 1 than in AVHRR band 2, where they are practically indistinguishable. Due to the spatial resolution of AVHRR data, the shaded-areas category included areas of both snow and rock. Overall, an AVHRR band 2/band 1 image ratio was found to be the most appropriate discriminator for blue-ice mapping.

The main reason for the reduced contrast between snow and blue ice in the Jutulstraumen area compared to Jutulsessen is the generally lower snow albedo in this area (Table 3). This reduction of snow albedo is caused by strong metamorphosis and surface melt. The presence of liquid water leading to grain growth tends to lower the infrared albedo in particular. In this area, radiation and melt processes, such as the formation of (micro) penitents and a winter snowpack that gradually melts away, occur on a yearly basis as described by Bøggild and Winther (1995) and Winther and others (1996). From Table 3 it is obvious that the satellite-derived albedo of snow is lower in the western area of Jutulstraumen, which corresponds to field observations (Winther and others, 1996). In this area there also exist "frozen lakes" consisting of refrozen meltwater that has collected in depressions and formed large lake-like features. Some of these "frozen lakes" are $>1 \mathrm{~km}^{2}$ in area. As for the surrounding blue-ice areas, these "frozen lakes" have a frozen top layer of $10-20 \mathrm{~cm}$ of ice with liquid water present beneath it (Winther, 1993; Bøggild and others, 1995; Winther and others, 1996; Liston and others 1999a, b, 2000). The "frozen lakes" have significantly lower albedo than blue ice in TM bands 2-4 (Table 3 ).

The blue-ice albedo in TM band 4 is significantly higher in Jutulstraumen than in Jutulsessen (Tables 2 and 3). We believe this is due to ice-bound snow crystals present in the Jutulstraumen blue-ice area. Another explanation might be that higher surface reflectance occurs from glazed surfaces in such a "melt-induced blue-ice" area, whereas in Jutulsessen 
rocks and debris from neighbouring mountains tend to lower the overall albedo. Because of the scattered appearance of blue ice in Jutulstraumen, the effect of mixed pixels also cannot be excluded as a possible explanation.

A general trend in this area is that the lowest brightness values are found closest to the Jutulstraumen ice stream, with successively increasing values towards the east (Table 3). This tendency corresponds well with the surface elevation pattern in this area, where we find areas close to sea level in the vicinity of Jutulstraumen, and gradually increasing elevations towards the east. Also, from several field campaigns we have observed that melt-affected areas occur more frequently in the west at lower elevations than at higher elevations in the east (Liston and others, 1999a). We have therefore separated blue-ice areas in the Jutulstraumen region derived by Landsat TM data into four classes $(\mathrm{A}-\mathrm{D})$, determined by their distance from the Jutulstraumen ice stream. Category A represents blue ice closest to the ice stream while category $\mathrm{D}$ represents the blue ice located farthest to the east, at highest elevation (Table 5).

The relative performances of the AVHRR and Landsat TM classifications for Jutulsessen and Jutulstraumen are shown in Table 5. We see that the AVHRR classification underestimates the blue-ice area considerably. For Jutulsessen, this is mostly caused by AVHRR pixels being obscured by shadows from nunataks and consequently not included as blue-ice areas. Accounting for this effect, caused by the difference in spatial resolution of the two sensors, increases the total area of blue ice classified by AVHRR to about $263 \mathrm{~km}^{2}$, approximately $28 \%$ less than for the Landsat classification. In the Jutulstraumen area, the discrepancy is smaller (about $14 \%$ ) if AVHRR pixels defined as "uncertain" are assumed to be blue ice. It is likely, however, that this group consists of a large number of mixed pixels with blue-ice portions of 0 $100 \%$, making the real difference between Landsat and AVHRR classification much higher and most probably also higher than for Jutulsessen. This is an example of the problems, inaccuracies and weaknesses introduced by using

Table 5. Comparison of classified blue-ice areas in futulsessen and Futulstraumen using NOAA AVHRR and Landsat TM

\begin{tabular}{|c|c|c|c|c|c|}
\hline & Futulsess & & & Futulstrat & men \\
\hline & Number of pixels & Area & & Number of pixels & Area \\
\hline & & $\mathrm{km}^{2}$ & & & $\mathrm{~km}^{2}$ \\
\hline NOAA & & & & & \\
\hline Blue ice & 126 & 128.5 & & 525 & 535.5 \\
\hline Uncertain & 132 & 134.6 & & 645 & 657.9 \\
\hline Total & 258 & 263.1 & & 1170 & 1193.4 \\
\hline$T M$ & & & & & \\
\hline $100 \%$ & 213696 & 192.3 & & & \\
\hline $75 \%$ & 25601 & 23.1 & & & \\
\hline $50 \%$ & 68271 & 61.5 & & & \\
\hline $25 \%$ & 97138 & 87.4 & & & \\
\hline Total & 404706 & 364.3 & & & \\
\hline & & & A & 319214 & 287.3 \\
\hline & & & B & 301688 & 271.5 \\
\hline & & & $\mathrm{C}$ & 377907 & 340.1 \\
\hline & & & $\mathrm{D}$ & 546027 & 491.4 \\
\hline & & & Total & 1544836 & 1390.3 \\
\hline
\end{tabular}

Notes: For the Jutulstraumen area, blue-ice areas are divided into four classes $(\mathrm{A}-\mathrm{D})$ depending on their distance from the Jutulstraumen ice stream ( $\mathrm{A}$ is closest; D is farthest away and at highest elevations; see text for details). sensors with low spatial resolution; these comments apply to both "wind-induced" and "melt-induced blue-ice" areas.

In scene 16 , blue ice is mainly classified in regions covered by outlet glaciers and slopes towards and on Lambert Glacier and Amery Ice Shelf (Fig. 5). The "wind-induced blue-ice" type (dark blue) generally occurs on Lambert Glacier, with a gradual change towards "blue-ice melt-induced" type (light blue) at lower elevations on the interior parts of Amery Ice Shelf (Fig. 5). The "potential/uncertain blue-ice" type (green) is normally found in the outlying areas but also at low elevations on the Amery Ice Shelf (Fig. 5). In the outermost (i.e. eastern) parts of the ice shelf no areas are classified as blue ice. Blue ice of both types is classified along the edges of the ice shelf, the eastern edge near Gillock Island being a prominent example. Other blue-ice areas as reported by Swithinbank (1991) are generally identified by the classification algorithm. On outlet glaciers draining into the Amery Ice Shelf, many blue-ice areas are classified. H. A. Fricker (personal communication, 1999) confirmed that field investigations discovered extensive blue ice in this area. The large blue-ice areas are likely to be caused by strong katabatic winds along Lambert Glacier. Classification statistics for scene 16 are given in Table 6. Altogether, about $37 \%$ of the "wind-induced blue-ice" areas in Antarctica are found in the Lambert Glacier region (Table 1).

The northernmost classified areas (mainly the "uncertain" class) in Figure 5 may be the result of melt phenomena in the snowpack and thus may not directly indicate the presence of blue ice. Around the northern border of the uncertain classification (about $71^{\circ} \mathrm{S}$ ), a thin snow layer $(<10 \mathrm{~cm})$ has been observed on top of bubbly ice (personal communication from H. A. Fricker, 1999). This is a good example of why it can be difficult to classify blue ice from AVHRR data for certain surface types or under special conditions. Another possible misclassification occurs on the areas of Lambert Glacier where "wind-induced blue-ice" areas are surrounded by "melt-induced blue-ice" areas (Fig. 5). Here, a combination of optical and radar sensors could have proved useful since radar sensors are sensitive to the presence of liquid water. Very few blue-ice areas are classified outside the Amery Ice Shelf, but some smaller areas exist in outer parts of the Prince Charles Mountains and Goodspeed Nunataks. The histograms for the three blueice categories for scene 16 are shown in Figure 7.

For scene 30, which is divided into three parts (Fig. 1), blue ice is classified only in the western scene (the largest one) and predominantly on outlet glaciers and on the lee side of mountains. The largest areas appear on the Byrd,

Table 6. Classification statistics of scene 16 (region: Lambert Glacier and Amery Ice Shelf), characterized by the range of $D \mathcal{N}$ intervals that occur for three different surface types

\begin{tabular}{cccc}
\hline AVHRR band & $\begin{array}{c}\text { Melt-induced" } \\
\text { blue ice }\end{array}$ & $\begin{array}{c}\text { "Wind-induced" } \\
\text { blue ice }\end{array}$ & Snow \\
\hline 1 & $100-120(109.8 ; 11.23)$ & $120-140(130.6 ; 12.73)$ & $150-190$ \\
2 & $80-102(93.6 ; 10.29)$ & $102-120(111.3 ; 4.82)$ & $130-170$ \\
$2 / 1$ & $39-43(40.8 ; 2.66)$ & $43-46(44.5 ; 4.03)$ & $45-50$
\end{tabular}

Notes: Mean values for a particular combination of surface type and AVHRR band, together with their corresponding standard deviation, are given in parentheses. 
Wind-induced blue ice

AVHRR band 2/1
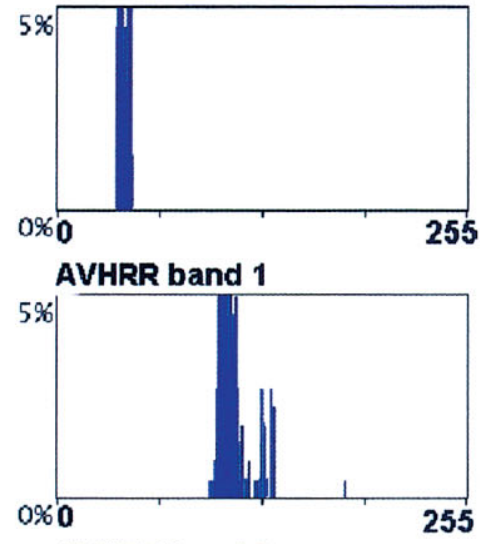

AVHRR band 2

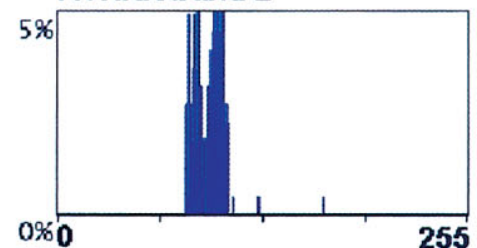

Melt-induced blue ice

AVHRR band 2/1

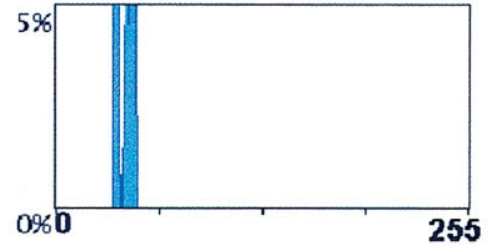

AVHRR band 1

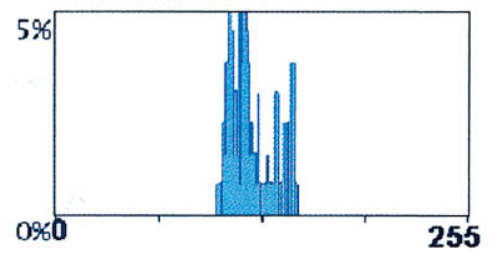

AVHRR band 2



Potential blue ice



AVHRR band 1

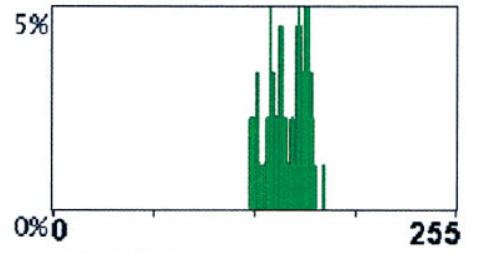

AVHRR band 2

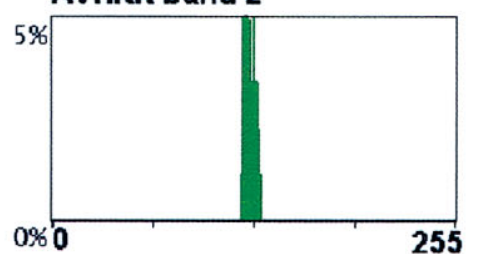

Horizontal axis: Digital Numbers, DN (0-255). Vertical axis: \% occurrence

Fig. 7. Histograms for the three blue-ice categories, "wind-induced", "melt-induced" and "potential/uncertain", respectively, from AVHRR mosaic scene 16 (i.e. Lambert Glacier basin).

Nimrod, Beardmore, Shackleton, Scott and Amundsen outlet glaciers. Here, shadows have a limited effect on the classification due to a favourable orientation of the sun with respect to the local topography. This is directly in opposition to scene 26 covering the northern part of the mountain range, where several misclassifications caused by shadows occur. The other major blue-ice locations reported by Swithinbank (1991) (Mount Prestrud, Kukri Rocks, Ellis Bluff, Adams Mountain, Wyandot Range, Mount Nichols and Baldwin Glacier) are spread over large parts of the mountain range and are also detected by the AVHRR classification. Additionally, many other areas are classified as blue ice, all of which are located on outlet glaciers and near mountains, probably indicating that the classification is correct. No blue ice is detected on the Ross Ice Shelf or in the two eastern parts of scene 30 that are located in the interior where there are no mountains.

Final amounts of classified blue-ice pixels of individual scenes are shown in Table 1 . About $60000 \mathrm{~km}^{2}$ are classified as "melt-induced blue-ice" and a similar amount as "windinduced blue-ice" areas. "Uncertain/potential blue-ice" areas cover $120000 \mathrm{~km}^{2}$. It would be useful to quantify the percentage of the latter category that actually contains blue-ice areas, but this has not been possible due to very limited ground-reference data for verification, seasonal variations that affect these areas differently for different times of data acquisition, and the very diffuse transitions/ boundaries between this category and the surroundings. However, we believe a large proportion of this category consists of melt- affected snow rather than blue ice. These areas appear mainly at coastal locations where melting can occur without necessarily creating areas of blue ice. We believe the "uncertain/ potential blue-ice" category comprises considerably less than $50 \%$ blue ice.

\section{CONGLUSIONS AND OUTLOOK}

Within the limits determined by the sensor characteristics of AVHRR and processing of the mosaic, we have mapped and quantified blue-ice areas in Antarctica. Areas where snow erosion and sublimation are the main mechanisms causing annual net ablation are generally well defined and thus relatively easy to detect. We call these "wind-induced blue-ice" areas. Approximately $37 \%$ of these areas are found in the Lambert Glacier drainage basin. In other areas, surface melting and katabatic winds are the main mechanisms for creating what we call "melt-induced blueice" areas. These generally have a more patchy appearance than the "wind-induced blue-ice" areas, often being surrounded by snow-covered surfaces creating mixed pixels. They are normally located in coastal regions. They also tend to have lower snow albedo (due to surface melt) and higher blue-ice albedo (due to the presence of ice-bound snow crystals, a relatively high amount of encapsulated air bubbles and the absence of debris - all three tending to raise the surface albedo) compared to the areas where "wind-induced blue ice" occurs, making it difficult to separate snow and blue ice here (Tables 2 and 3).

Each of the two groups covers approximately 60000 $\mathrm{km}^{2}$, and together they constitute about $0.8 \%$ of the Antarctic continent. Therefore, a conservative estimate of Antarctic blue-ice areas based on this method is $120000 \mathrm{~km}^{2}$. Additionally, we have identified another $121000 \mathrm{~km}^{2}$ of potential blue-ice areas. These estimates are in good agreement with Bintanja (1999) who reported that blue-ice areas occupied about 1\% of Antarctica. Further research should seek to improve the classification of these "uncertain" areas which, using AVHRR data, we cannot claim with certainty to be blue ice.

The occurrence of blue-ice areas is relevant to many 
aspects of meteorological, glaciological and climatological research (e.g. energy-budget calculations), so a precise quantification of blue-ice areas is important. One major motivation for us has been to obtain a dataset that can be used to model surface and near-surface melt in Antarctica. Examples of other applications of satellite-derived mapping of blue-ice areas are (i) modelling of surface energy and mass balance, (ii) localization of areas where horizontal stratigraphy (or isochrones that can be used for dating purposes) exist, (iii) sizechange detection used as a climatic indicator of surface massbalance variations, and (iv) identification of potential meteorite accumulation sites. Some of these applications would benefit from using satellite data with higher spatial resolution than the NOAA AVHRR data.

New operational optical satellites such as the Terra (EOS AM-1), with its moderate-resolution imaging spectroradiometer sensor that has improved spectral and spatial resolution $(500 \mathrm{~m})$, will be appropriate tools for improving the quantitative measures of this study. We also suggest repeating mapping of the blue-ice areas at a later time in order to evaluate changes that may occur over time in Antarctica. A development of our work and a valuable historical "benchmark" of blue-ice distribution in Antarctica would be to establish a blue-ice classification based on the original AVHRR data, allowing data of quantifiable radiometry. Finally, a combined use of optical and radar satellites, such as RADARSAT, could also be helpful for future blue-ice classification.

\section{ACKNOWLEDGEMENTS}

We would like to thank the following persons who have assisted us in various ways and have thus contributed to the final results obtained in this study: I. Allison (Australian Antarctic Division and Antarctic CRC), J. Ferrigno (USGS), H. A. Fricker (University of California, San Diego), G. K. Langlo (Alfred Wegener Institute, Germany), A. Ruddell (Australian Antarctic Division and Antarctic GRC), T. Scambos (U.S. National Snow and Ice Data Center (NSIDC)), J. A. Stapleton (USGS), C. Swithinbank (Scott Polar Research Institute, U.K.) and J. Wolfe (NSIDC). We also would like to express our gratitude to two anonymous reviewers and the scientific editor, H. Rott, who helped us to improve the quality of this paper. Financial support was provided by the Norwegian Research Council and the Norwegian Polar Institute.

\section{REFERENCES}

Allison, I. 1998. Surface climate of the interior of the Lambert Glacier basin, Antarctica, from automatic weather station data. Ann. Glaciol., 27, 515-520.

Allison, I., N.W. Young and T. Medhurst. 1985. Correspondence. On reassessment of the mass balance of the Lambert Glacier drainage basin, Antarctica. 7. Glaciol., 31 (109), 378-381.

Bindschadler, R. and P. Vornberger. 2000. Detecting ice-sheet topography with AVHRR, RESURS-01, and Landsat TM imagery. Photogramm.
Eng. Remote Sensing, 66(4), 417-422.

Bintanja, R. 1999. On the glaciological, meteorological and climatological significance of Antarctic blue ice areas. Rev. Geophys., 37(3), 337-359.

Bintanja, R. and M. R. van den Broeke. 1995a. The climate sensitivity of Antarctic blue-ice areas. Ann. Glaciol., 21, 157-161.

Bintanja, R. and M. R. van den Broeke. 1995b. The surface energy balance of Antarctic snow and blue ice. 7. Appl. Meteorol., 34(4), 902-926.

Bøggild, C. E. and J.-G. Winther. 1995. A newly detected ablation phenomenon in Dronning Maud Land, Antarctica. Gronl. Geol. Undersøgelse, Rapp. 165, 93-96.

Bøggild, C. E., J.-G. Winther, K. Sand and H. Elvehøy. 1995. Sub-surface melting in blue-ice fields in Dronning Maud Land, Antarctica: observations and modelling. Ann. Glaciol., 21, 162-168.

Ferrigno, J. G. and 7 others. 1996. Satellite image map of Antarctica. Washington, DC, United States Geological Survey. (USGS Miscellaneous Field Investigations Map I-2560, scale 1:5,000,000.)

Jespersen, M. N. 2000. Blue-ice mosaic of Antarctica. (M.Sc. thesis, Technical University of Denmark.)

Lange, G. 1996. Sonne, Sturm und weisse Finsternis - Die Chronik der ostdeutschen Antarktisforschung. Hamburg, Kabel Verlag.

Liston, G. E., J.-G. Winther, O. Bruland, H. Elvehøy and K. Sand. 1999a. Below-surface ice melt on the coastal Antarctic ice sheet. F. Glaciol., 45(150), 273-285.

Liston, G. E., O. Bruland, J.-G. Winther, H. Elvehøy and K. Sand. 1999b. Meltwater production in Antarctic blue-ice areas: sensitivity to changes in atmospheric forcing. Polar Res., 18(2), 283-290.

Liston, G. E., J.-G. Winther, O. Bruland, H. Elvehøy, K. Sand and L. Karlöf. 2000. Snow and blue-ice distribution patterns on the coastal Antarctic ice sheet. Antarct. Sci., 12(1), 69-79.

Mellor, M. and C. Swithinbank. 1989. Airfields on Antarctic glacier ice. CRREL Rep. 89-21.

Merson, R. H. 1989. An AVHRR mosaic image of Antarctica. Int. F. Remote Sensing, 10(4-5), 669-674.

Orheim, O. and B. Lucchitta. 1990. Investigating climate change by digital analysis of blue ice extent on satellite images of Antarctica. Ann. Glaciol., 14, $211-215$

Phillips, H. A. 1998. Surface meltstreams on the Amery Ice Shelf, East Antarctica. Ann. Glaciol., 27, 177-181.

Schytt, V. 1961. Glaciology II(E). Blue ice-fields, moraine features and glacier fluctuations. Norwegian-British-Swedish Antarctic Expedition, 1949-52. Sci. Results IV, 181-204.

Swithinbank, C.W. M. 1991. Potential airfield sites in Antarctica for wheeled aircraft. CRREL Spec. Rep. 91-24.

Van den Broeke, M. R. 1997. Spatial and temporal variation of sublimation on Antarctica: results of a high-resolution general circulation model. $\mathcal{F}$. Geophys. Res., 102(D25), 29,765-29,777.

Van den Broeke, M. R. and R. Bintanja. 1995. The interaction of katabatic winds and the formation of blue-ice areas in East Antarctica. F. Glaciol., 41 (138), 395-407.

Warren, S. G., R. E. Brandt and R. D. Boime. 1993. Blue ice and green ice. Antarct. F. U.S., $28(5)$, Review 1993, 255-256.

Winther, J.-G. 1993. Studies of snow surface characteristics by Landsat TM in Dronning Maud Land, Antarctica. Ann. Glaciol., 17, 27-34.

Winther, J.-G. 1994. Spectral bi-directional reflectance of snow and glacier ice measured in Dronning Maud Land, Antarctica. Ann. Glaciol., 20, 1-5.

Winther, J.-G., H. Elvehøy, C. E. Bøggild, K. Sand and G. Liston. 1996. Melting, runoff and the formation of frozen lakes in a mixed snow and blue-ice field in Dronning Maud Land, Antarctica. F. Glaciol., 42(141), 271-278.

Winther, J.-G., S. Gerland, J. B. Ørbæk, B. Ivanov, A. Blanco and J. Boike. 1999. Spectral reflectance of melting snow in a high Arctic watershed on Svalbard: some implications for optical satellite remote sensing studies. Hydrol. Processes, 13(12-13), 2033-2049.

Winther, J.-G., S. Gerland, J. B. Ørbæk, B. Ivanov, A. S. Zachek and A. M. Bezgreshnov. 2001. Effects on spectral reflectance from snow ageing. Natl. Inst. Polar Res. Mem. 54, 193-201.

Yoshida, M., H. Ando, K. Omoto and Y. Ageta. 1971. Discovery of meteorites near Yamato Mountains, East Antarctica. Antarct. Rec., 39, 62-65. 